Pak. j. sci. ind. res. Ser. B: biol. sci. 201255 (3) 138-144

\title{
Effects of Passiflora foetida Linn. (Passifloraceae) on Genital Tract, Serum Estradiol, Pituitary Gonadotropin and Prolactin Level in Female Adult and Immature Ovariectomized Rats
}

\author{
Bleu Gome Michel*a, Kouakou Koffi ${ }^{b}$, Toure Alassane ${ }^{c}$ and Traore Flavien a \\ ${ }^{a}$ Laboratory of Animal Physiology, UFR Biosciences, University of Cocody, \\ Abidjan, 22 BP 582 Abidjan 22, Côte d'Ivoire \\ ${ }^{b}$ Laboratory of Biology of Reproduction and Endocrinology, UFR Biosciences, University of Cocody, \\ Abidjan, 22 BP 582 Abidjan 22, Côte d'Ivoire \\ ${ }^{\mathrm{c}}$ Division of Anatomy-Pathology, Central Laboratory of Veterinary Medicine (LANADA), \\ Bingerville, BP 206 Bingerville, Côte d'Ivoire
}

(received August 26, 2011; revised August 6, 2012; accepted September 4, 2012)

\begin{abstract}
The effects of the extracts of Passiflora foetida on the genital tract, serum estradiol, pituitary gonadotropin (LH and FSH) and prolactin were studied in female adult (120-140 g) and immature ovariectomized (30-40 g) rats. Results showed that the aqueous extract increased significantly both the ovary and uterus weight whereas the hexane extract increased the weight of the ovary only and the methanol extract increased the weight of uterus only. Histological examination of these organs indicated that $P$. foetida treated rats were in estrous or proestrous phases of the estrous cycle. The hormone analysis showed that the serum LH was significantly increased by $17 \beta$ estradiol and by the three extracts dose dependently in immature ovariectomized rats. Moreover, the aqueous extract increased significantly serum estradiol and pituitary gonadotropins and prolactin in adult non ovariectomized rats.
\end{abstract}

Keywords: Passiflora foetida, ovary, uterus, estradiol, gonadotropins, prolactin

\section{Introduction}

According to the World Health Organization, $80 \%$ of the population in Africa depends on traditional medicine for their health-care needs (WHO, 2002). This continent is endowed with a rich biodiversity estimated about 40,000 plant species (Mahunnah, 2002) and more than 4000 species are used medicinally (Bosh et al., 2002). Infertility is one of the most crucial health problems which are treated in the African traditional medicine. This reproductive problem causes divorces, instability and polygamy in many families where some women considered as sterile are victims of violence (Papreen et al., 2000; Unissa, 1999). Hence, most of them use medicinal plants to recover their fecundity (KambuKabangu, 1990) due to poverty. Passiflora foetida is a medicinal plant used by population in the south of Côte d'Ivoire to cure infertility in women (N'Guessan, 2008; 1995). Furthermore, it serves to treat other diseases such as snakebites, epilepsy, and abscess (N'Guessan, 2008; 1995; Adjanohoun and Aké-Assi, 1979). It is used in Asia continent as emmenagogue and as remedy for asthma, biliousness, hysteria, giddiness and headache (Dhawan et al., 2004). The major phytochemical consti*Author for correspondence; E-mail: bleugomez@yahoo.fr tuents of this plant are flavonoids, glycosides, phenolic compounds, fats, steroids and alkaloids (Patel et al., 2011; Ingale and Hivrale, 2010; Echeverri et al., 2001; Cambie and Ash, 1994). This study was aimed to evaluate the effects of Passiflora foetida leaves on the genital tract, estrogen and pituitary hormone levels in female wistar rats.

\section{Materials and Methods}

Plant material. The leaves of $P$. foetida were collected from the north and the south of Abidjan, the economic capital city of Côte d'Ivoire and authenticated in the Laboratory of Botany (UFR Biosciences) of the University of Cocody, Abidjan. A voucher specimen was deposited in the botanical garden of this University under the number $746 \mathrm{~B}$.

Preparation of the extracts. The collected plant material was dried at an ambient temperature $\left(30 \pm 2{ }^{\circ} \mathrm{C}\right)$ without exposure to sun light and crushed to obtain a powder which was divided into three parts, $50 \mathrm{~g}$ of each were macerated separately for $24 \mathrm{~h}$ in water $(1500 \mathrm{~mL})$, hexane $(750 \mathrm{~mL})$ and methanol $95^{\circ}(750 \mathrm{~mL})$, filtered using Whatman filter paper number 1 and concentrated in an air circulating oven at $50{ }^{\circ} \mathrm{C}$ until total dryness. 
The aqueous, hexane and methanol extracts obtained (yield $20.23 \%, 6.83 \%$ and $28.03 \%$ respectively) were then stored at $4{ }^{\circ} \mathrm{C}$ in a refrigerator for the experimental studies.

Effects on the genital tract. Adult female wistar albino rats (120-140 g) were divided into groups of 5 rats each and administered separately the dose of $500 \mathrm{mg} / \mathrm{kg}$ body weight of each extract for 14 and 28 days. The control group was treated with olive oil. All the treatments were given orally, using an intragastric cannula. At the day after the last treatment, the rats were weighed and sacrificed by decapitation under light ether anesthesia. The ovary and uterus of each rat were dissected out and weighed rapidly using a sensitive balance. The adrenal and kidney were also dissected and weighed. Additionally, the dissected organs were fixed in bouin's fluid for $24 \mathrm{~h}$, dehydrated and embedded in paraffin. The paraffin sections were cut at $4 \mu \mathrm{m}$ and stained with haematoxylin-eosin for histological examinations.

Effects on LH level of immature ovariectomized rats. The immature female albino rats $(30-40 \mathrm{~g})$ were bilaterally ovariectomized (ovx) under light ether anesthesia through lateral incision in the skin just below the last rib (Keshri et al., 1995; Zarrow et al., 1964). After a post operative rest period of 7 days, the rats were divided into 8 groups of 6 animals each and treated separately with olive oil (control group), $0.02 \mathrm{mg} / \mathrm{kg}$ body weight of $17 \beta$ estradiol, the high dose $(500 \mathrm{mg} / \mathrm{kg}$ body weight) and low dose ( $250 \mathrm{mg} / \mathrm{kg}$ body weight) of each extract. All the treatments were given orally for 7 consecutive days and $24 \mathrm{~h}$ after the last treatment, the rats were anesthetized with ether and sacrificed by decapitation. The blood samples were collected into non heparinized tubes and centrifuged at $2580 \mathrm{rpm}$ for $10 \mathrm{~min}$. The serum was then separated and stored at $-20{ }^{\circ} \mathrm{C}$ until $\mathrm{LH}$ analysis by the ELFA technique (Enzyme Linked Fluorescent Assay) using specific kit (BioMerieux, Lyon, France).

Effect on serum estrogen, gonadotropins and prolactin of adult rat. The aqueous extract was found to be the most active extract on the genital tract and on LH level of ovx rat. Hence, it was used to determine the effect of $P$. foetida on estrogen and pituitary hormones. For this experiment, female adult rats were divided into two groups of 5 rats each. The first group served as control and received olive oil only and the second group was treated with a dose of $500 \mathrm{mg} / \mathrm{kg}$ body weight of the aqueous extract by gavage for 28 consecutive days. At the end of the treatment, the rats were sacrificed under ether anesthesia and the collected blood samples were analyzed for the level of estrogen $\left(\mathrm{E}_{2}\right)$, gonadotropin ( $\mathrm{LH}$ and $\left.\mathrm{FSH}\right)$ and prolactin (PRL) in the serum by the same methods used in the previous experiment.

Statistical analysis. The data were expressed as mean \pm SEM. Statistical analysis of the variance between control and experimental values were done using student's t-test. A probability level of less than 5\% $(p<0.05)$ was considered significant.

\section{Results and Discussion}

Effects on ovary and uterus weight. The effect of P. foetida on the weight of ovary, uterus, adrenal and kidney of adult female rats are presented in the Table 1. The extracts did not induce any change in the weight

Table 1. Effects of $P$. foetida on the weight of ovary, uterus, adrenal and kidney of female adult rats

\begin{tabular}{|c|c|c|c|c|c|}
\hline \multirow[t]{2}{*}{ Treatments } & \multirow{2}{*}{$\begin{array}{l}\text { Duration } \\
\text { (days) }\end{array}$} & \multicolumn{4}{|c|}{ Organ weight (mg/100 g body weight) } \\
\hline & & Kidney & Ovary & Uterus & Adrenal \\
\hline \multirow[t]{2}{*}{ Control (olive oil) } & 14 & $274.79 \pm 21.88$ & $16.80 \pm 3.69$ & $152.63 \pm 12.67$ & $13.65 \pm 1.47$ \\
\hline & 28 & $276.41 \pm 20.86$ & $17.50 \pm 4.44$ & $151.45 \pm 14.85$ & $13.81 \pm 2.32$ \\
\hline \multirow[t]{2}{*}{$\mathrm{AE}(500 \mathrm{mg} / \mathrm{kg})$} & 14 & $265.43 \pm 19.65$ & $28.65 \pm 3.77^{* *}$ & $188.19 \pm 18.06^{* *}$ & $13.22 \pm 2.18$ \\
\hline & 28 & $268.32 \pm 13.84$ & $25.27 \pm 3.21^{*}$ & $216.89 \pm 35.07^{* *}$ & $12.83 \pm 2.39$ \\
\hline \multirow[t]{2}{*}{ HE $(500$ mg/kg) } & 14 & $262.42 \pm 12.73$ & $27.74 \pm 7.23^{*}$ & $133.98 \pm 35.83$ & $12.76 \pm 3.29$ \\
\hline & 28 & $273.39 \pm 26.87$ & $28.82 \pm 3.49^{* * *}$ & $143.79 \pm 37.54$ & $11.48 \pm 1.76$ \\
\hline \multirow[t]{2}{*}{ ME (500 mg/kg) } & 14 & $295.91 \pm 23.22$ & $17.67 \pm 2.90$ & $189.04 \pm 13.94^{* *}$ & $12.37 \pm 2.71$ \\
\hline & 28 & $283.77 \pm 8.94$ & $16.65 \pm 372$ & $225.44 \pm 31.29^{* *}$ & $13.26 \pm 1.31$ \\
\hline
\end{tabular}

Values are means \pm SEM $(\mathrm{n}=5) ; *=\mathrm{p}<0.05 ; * *=\mathrm{p}<0.01 ; * * *=\mathrm{p}<0.001 ; \mathrm{AE}=$ aqueous extract; HE = hexane extract; $\mathrm{ME}=$ methanol extract. 

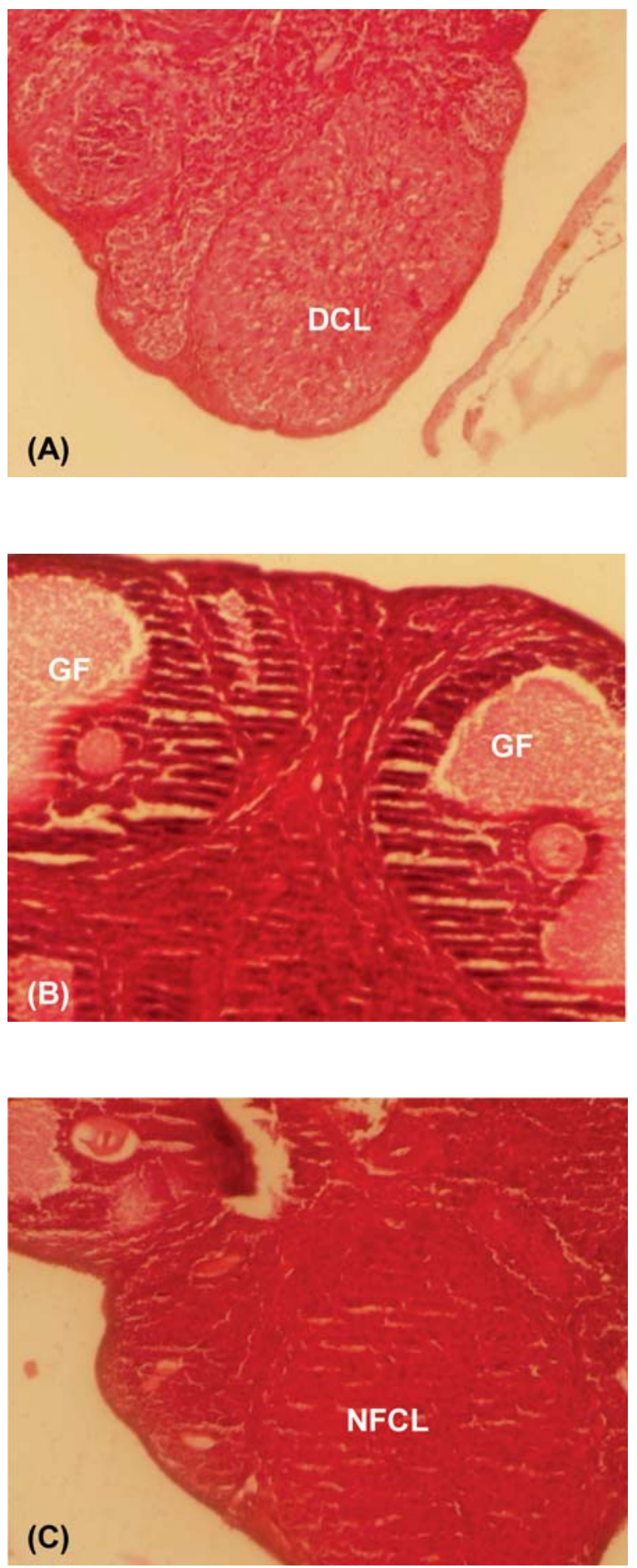

Fig. 1(A-C). Photomicrograph of the ovaries in rats showing degenerated corpora lutea (DCL) in control rats (A) and Graafian follicles (GF) and newly formed corpora lutea (NFCL) in $P$. foetida treated rats $(\mathrm{B}$ and $\mathrm{C})$. Original magnification $\times 10$; stained: Haematoxylin-eosin. and histological structure of kidney and adrenal. However, the aqueous extract induced significant increase in the weight of ovary and uterus after 14 days and 28 days of treatment. The hexane extract induced only significant increase of ovary weight whereas the methanol extract increased significantly only the uterine weight after 14 and 28 days of treatment when compared to control group. Furthermore, the 14 days treatmentinduced weight changes were not significantly different from those of the 28 days treatment.

The histological examination of the ovaries of both the aqueous and hexane extracts treated groups showed the presence of newly formed corpora lutea or Graafian follicles in all the rats. Control group showed degenerated corpora lutea without any presence of Graafian follicles in $80 \%$ of the rats (Fig. 1A-C). Histological evaluation of the uterus indicated that the endometrial epithelium of the aqueous and methanol extract-treated rats consisted of tall columnar cells with apoptotic and/or mitotic figures. Endometrial epithelium of the control rats included small, low columnar cells (Fig. 2A-B).

Effects on serum level of LH of ovx rats. There was a dose dependent increase in $\mathrm{LH}$ in the serum of immature ovx rats by all the extracts and by $17 \beta$ estradiol. However, the effect of the extracts at the dose of $250 \mathrm{mg} / \mathrm{kg}$ was greater than that induced by the dose of $500 \mathrm{mg} / \mathrm{kg}$. The aqueous extract was found to be the most effective extract at the high dose $(500 \mathrm{mg} / \mathrm{kg})$ whereas the methanol extract was the most effective one at the low dose (250 mg/kg) (Fig. 3).

Effect on $E_{2}$ and the pituitary hormones of adult rats. The aqueous extract of $P$. foetida caused significant increase of gonadotropins ( $\mathrm{LH}$ and $\mathrm{FSH}$ ) and prolactin level in the serum of the adult female rats (Fig. 4A-B). The serum estrogen of the rats was also highly increased (Fig. 5).

The extracts did not change the weight or the histological architecture of the adrenal and kidney. So, P. foetida had no effect on these organs at doses up to and including $500 \mathrm{mg} / \mathrm{kg}$. However, the aqueous and hexane extracts caused significant increase in the ovary weight. These results are similar to those obtained by Thakur et al. (2009) with the ethanolic and aqueous extracts of Carum carvi and Curcuma longa and with ethinyl estradiol. They are also comparable to the effect of the phytoestrogen resveratrol on ovary weight (Henri and Witt, 2002). Estrogen is a steroid hormone synthesized by the ovary which regulates the physiology of the 
female genital tract (Freeman, 2008; Wassarman and Albertini, 1994). It can induce the increase of the ovarian weight by stimulating development and maturation of follicles (Wassarman and Albertini, 1994; Vaissaire, 1977; Smith and Bradbury, 1961). It is suspected that effects of the aqueous and hexane extract are the result of inherent phytoestrogens in the plant. The histological analysis of ovaries showed the presence of newly formed corpora lutea or Graafian follicles in all the treated rats indicating that these rats were in estrous or in proestrous phases of the estrous cycle, respectively. Control group
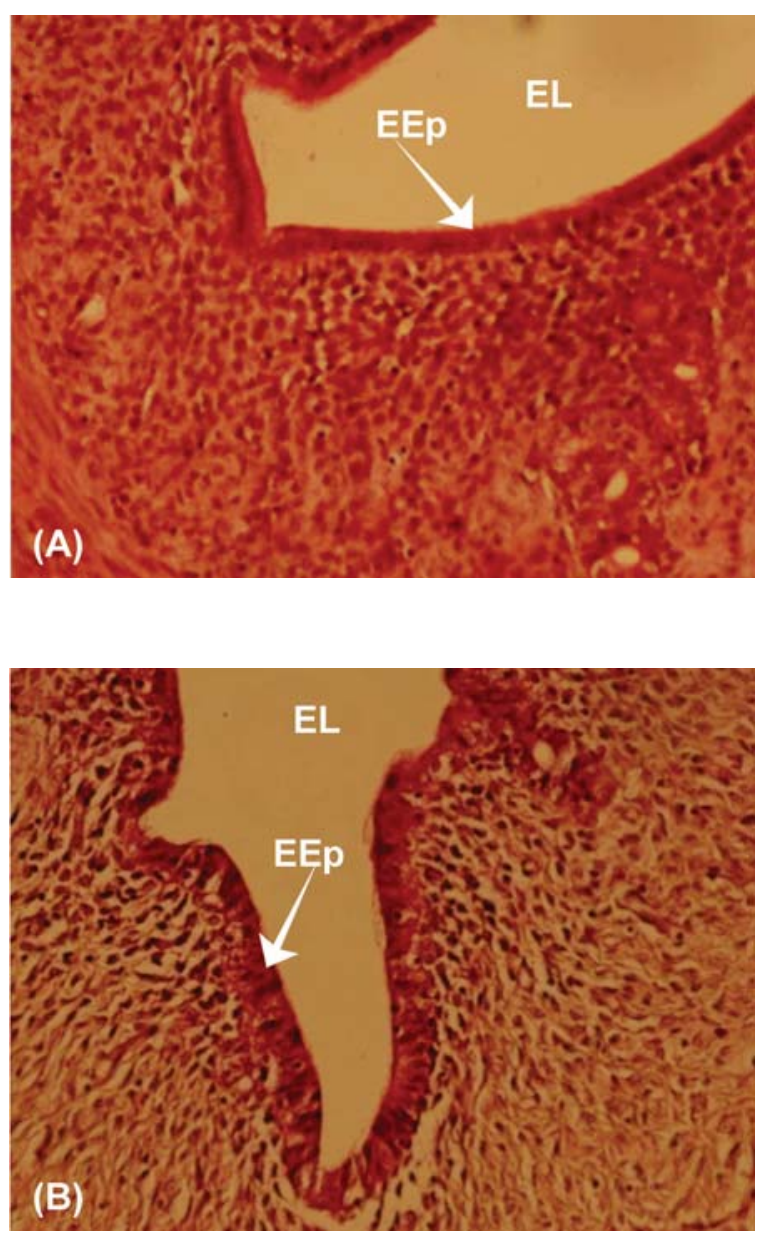

Fig. 2(A-B). Photomicrograph of the uterus showing low, small columnar endometrial epithelium cells in control rats (A) and tall columnar endometrial epithelium cells in the P. foetida treated rats (B). E = Endometrium; EEp $=$ Ednometrial epithelium; EL = Endometrial lumen. Original magnification $\times 10$; stained: Haematoxylin-eosin.

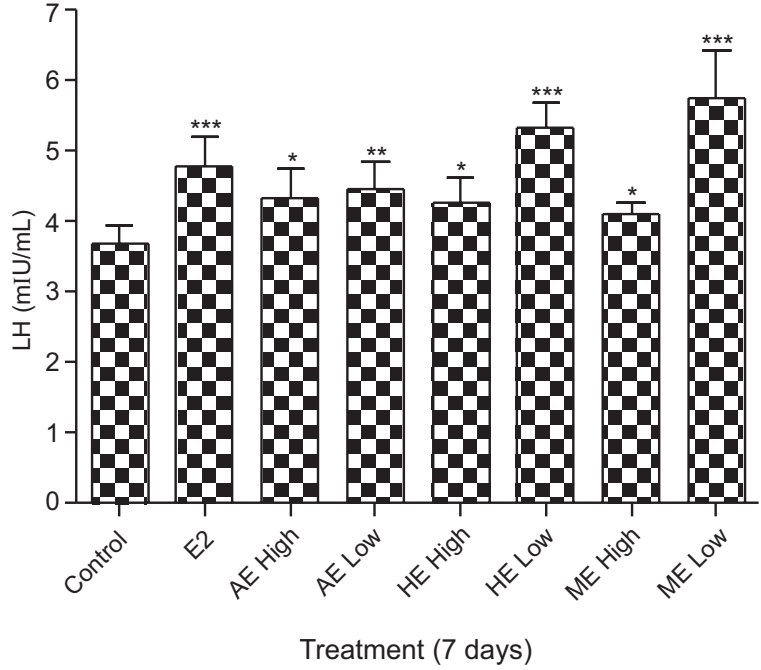

Fig. 3. Effects of $17 \beta$ estradiol and $P$. foetida on serum LH of immature OVX rats. Values are means \pm SEM $(\mathrm{n}=6) ; * \mathrm{p}<0.05 ; * * \mathrm{p}<0.01$; $* * * p<0.001$.

rats showed degenerated corpora lutea without presence of Graafian follicles comparable to those of metestrous and diestrous phases. Estrogen is well known to stimulate gonadotropins surge which induce follicles development and ovulation (Freeman, 2008; Haim et al., 2003; Mora et al., 1994). This result confirmed the potential estrogenic effect of these extracts. The uterine wet weight in this experiment was also increased by the treatment with the aqueous and methanol extracts. The same results have been obtained by Thakur et al. (2009) and Kouakou (2000) after administration of $17 \beta$ estradiol to adult rats. Estrogen stimulates uterus weight, endometrial proliferation and hyperplasia by production of insulin-like growth factor I (IGF-I), expression of progesterone receptor and the complement protein $\mathrm{C} 3$ (Albertazzi and Sharma, 2005; Seidlova-Wuttke et al., 2003). The fact that $P$. foetida aqueous and methanol extracts increased the uterine weight suggests that they acted as estrogen-like, mimicking probably the estrogen mechanism of action in this organ. The histological examination of the uteri corroborated the weight changes since the endometrial epithelium of $P$. foetida treated group was composed of tall columnar cells with apoptotic and/or mitotic figures. The endometrium of the control rats was not proliferated and the epithelium consisted of small, low columnar cells.

As well as the genital tract, the hypothalamo-pituitary complex is a target organ of estrogen where it influences 

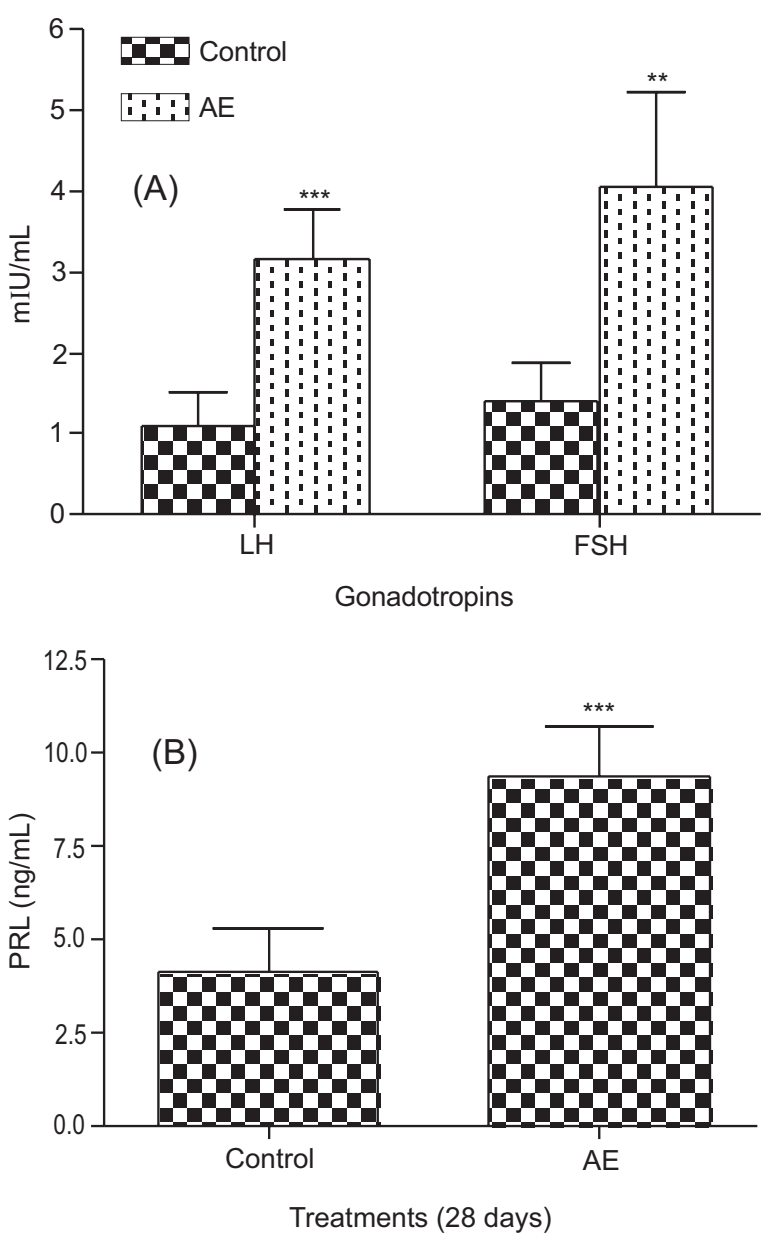

Fig. 4(A-B). Effects of $P$. foetida on pituitary gonadotropins (A) and prolactin (B) level in serum of adult female rats. Values are means $\pm \operatorname{SEM}(n=s) ; * p<0.01 ; * * * p<0.001$.

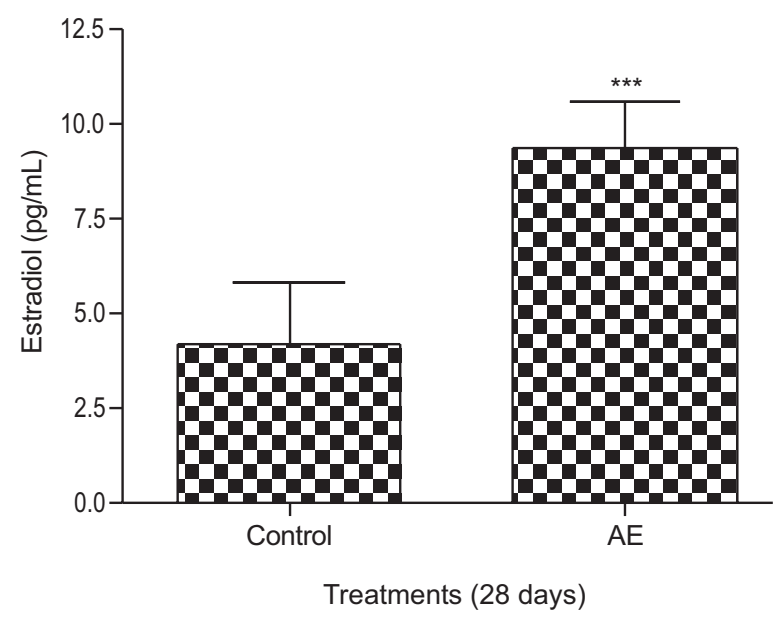

Fig. 5. Effects of $P$. foetida on serum estradiol of adult female rats. Values are means \pm SEM $(\mathrm{n}=5),{ }^{*} * \mathrm{p}<0.001$. indirectly the reproductive cycle using his receptor ER $\alpha$ and ER $\beta$ (Hraboyszky et al., 2000; Laflamme et al., 1998; Shughrue et al., 1997). In this study, when administered to immature ovx rats, $17 \beta$ estradiol and the extracts of $P$. foetida increased significantly the LH level in serum. Several earlier authors had reported similar results (Shinnosuke and Masahico, 1994; Shupnik et Rosenzweig, 1991; Rosen et al., 1989). Folliculogenesis and the secretion of estrogen in the ovary depend on gonadotropin (Monniaux et al., 2009; Wassarman and Albertini, 1994; Hodgen, 1989) but estrogen can modulate their secretion by feed back control (Christoffel et al., 2006; Shupnik, 1996; Garib et al., 1990). It is assumed that increase of LH in serum of ovx rats is the result of phytoestrogens present in the plant. The estrogenic nature of $P$. foetida was confirmed by the aqueous extract tested in adult non ovx rats to determine the effects on the pituitary hormones $(\mathrm{LH}$, FSH and PRL) and on estrogen. All these hormones were significantly increased by the treatment, showing that the estrogenic molecules in this plant did not compete with the endogenous estrogen, acting as agonists. The effects of $P$. foetida may be due to its phytochemical constituents such as flavonoids, alkaloids, steroids, polyphenols (Patel et al., 2011; Ingale and Hivrale, 2010; Cambie and Ash, 1994), substances which are known for their estrogenic effects (Diel et al., 2004; Nazrullaev et al., 2001; Baker et al., 1999). Hence, The results in this study were different from those obtained with the antifertility plants Trichosanthes cucumerina var cucumerina (Kage et al., 2009), Afromosia laxiflora, Pterocarpus erinaceus and Cola nitida (Benie et al., 2003) which were found to have antiestrogenic effects by reducing ovary weight and serum level of gonadotropin in adult non ovx rats.

\section{Conclusion}

P. foetida extracts exerts estrogen-like effects on female genital tract and pituitary gland. Further investigations must be carried out to isolate the active constituents and to elucidate their mechanism of action for the efficient use of this plant in the human reproductive problems.

\section{References}

Adjanohoun, E.J., Ake-Assi, L. 1979. Contribution au Recensement des Plantes Médicinales de Côte d'Ivoire, 358 pp., Centre National de Floristique, Abidjan, Côte d'Ivoire. 
Albertazzi, P., Sharma, S. 2005. Urogenital effect of selective estrogen receptor modulators: a systemic review. Climacteric, 8: 214-220.

Baker, V.A., Hepburn, K.S.J., Jones, P., Lea, L., Sumpter, J., Ashby, J. 1999. Safety evalution of phytosterol esters. Part 1: Assessment of oestrogenicity using a combination of in-vivo and in-vitro assays. Food and Chemical Toxicology, 37: 13-22.

Benie, T., Duval, J., Thieulant, M.L. 2003. Effects of some traditional plant extracts on rat estrous cycle compared with clomid. Phytotherapy Research, 17: 748-755.

Bosch, C.H., Siemonsma, J.S., Lemmens, R.H.M.J., Oyen, L.P.A. 2002. Plant Resources of Tropical Africa. Basic List of Species and Commodity Grouping, 341 pp., Plant Resources of Tropical Africa (PROTA) Program, Wageningen, The Netherlands.

Cambie, R., Ash, J. 1994. Fijian Medicinal Plants, 235 pp. CSIRO Publishing, Australia.

Christoffel, J., Rimoldi, G., Wuttke, W. 2006. Effects of 8-prenylnaringenin on the hypothalamo-pituitaryuterine axis in rats after 3-month treatment. Journal of Endocrinology, 188: 397-405.

Dhawan, K., Dhawan, S., Sharma, A. 2004. Passiflora: a review update. Journal of Ethnopharmacology, 94: 1-23.

Diel, P., Geis, R.B., Caldarelli, A., Schimidt, S., Leschowskey, U.L., Voss, A., Vollmer, G. 2004. The differential ability of the phytoestrogen genistein and of estradiol to induce uterine weight and proliferation in the rat is associated with a substance specific modulation of uterine gene expression. Molecular and Cellular Endocrinology, 22: 21-32.

Echeverri, F., Arango, V., Quinines, W., Torres, F., Escobar, G., Rosero V., Arshbold, R. 2001. Passifloricins, polyketides alpha-pyrone from Passiflora foetida resin. Phytochemistry, 56: 881-885.

Freeman, M.E. 2008. Neuroendocrine control of the ovarian cycle of the rat. In: Physiology of Reproduction, E. Knobil and D. N. Jimmy (eds.), vol. 2, pp. 2328-2387, $3^{\text {rd }}$ edition, Raven Press, New York, USA.

Gharib, S.D., Wierman, M.E., Shupnik, M.A., Chin, W.W. 1990. Molecular biology of the pituitary gonadotropins. Endocrinelogy Review, 11: 177-199.

Haim, S., Shakhar, G., Rossene, E., Taylor, A.N., BenEliyahu, S. 2003. Serum level of sex hormones and corticosterone throughout 4 and 5 days estrous cycles in Fischer 344 rats and their stimulation in ovariectomized females. Journal of Endocrinology Investigation, 26: 1013-1022.

Henri, L.A., Witt, D.M. 2002. Resveratrol: phytoestrogen effects on reproductive physiology and behavior in female rats. Hormones and Behaviour, 41: 220-228.

Hodgen, G.D. 1989. Neuroendocrinology of the normal menstrual cycle. The Journal of Reproductive Medicine, 34: $68-75$.

Hrabovszky, E., Shughrue, P.J., Merchenthaler, I., Carpenter, C.D., Liposits, Z., Petersen, S.L. 2000. Detection of estrogen receptor-beta messenger ribonucleic acid and ${ }^{125} \mathrm{I}$-estrogen binding sites in luteinizing hormone-releasing hormone neurons of the rat brain. Endocrinology, 14: 3506-3509.

Ingale, A.G., Hivrale, A.U. 2010. Pharmacological studies of Passiflora sp. and their bioactive compounds. African Journal of Plant Sciences, 4: 417-426.

Kage, D.N., Malashetty, V.B., Seetharam, Y.N., Suresh, P., Patil, S.B. 2009. Effect of ethanol extract of whole plant of Trichosanthes cucumerina var. cucumerina L. on gonadotropins, ovarian follicular kinetics and estrous cycle for screening of antifertility activity in albino rats. International Journal of Morphology, 27: 173-182.

Kambu-Kabangu. 1990. Eléments de phytothérapie comparée. Plantes médicinales africaines. Centre de recherche pédagogique, Kinshasa, 3: 12-106.

Keshri, G., Singh, M., Lakshimi, V., Kamboj, V.P. 1995. Post coital contraceptive efficacy of the seeds of Nigella sativa in rats. Indian Journal of Physiology and Pharmacology, 39: 59-62.

Kouakou, K. 2000. Etude des Effets Antifertilisants de l'Extrait de Deux Champignons (Daldinia concentrica Bolt, 1863 et Psathyrella efflurescens Berk, 1977) de la Pharmacopée Ivoirienne chez la Ratte. Thèse de Doctorat $3^{\text {ème }}$ cycle, 122 pp., Université de Cocody, Abidjan, Côte d'Ivoire.

Laflamme, N., Nappi, R.E., Drolet, G., Labrie, C., Rivest, S. 1998. Expression and neuropeptidergic characterization of estrogen receptor $(\mathrm{ER} \alpha$ and $\mathrm{ER} \beta$ ) throughout the rat brain: anatomical evidence of distinct roles each subtype. Journal of Neurobiology, 36: 357-378.

Mahunnah, R.L.A. 2002. Ethnobotany and conservation of plants in Africa: the way forward in the next decade, 2001-2010. In: Proceedings of the Fifteenth Meeting of the Inter-African Expert Committee on 
African Traditional Medicine and Medicinal Plants, Arusha, Tanzania, OUA Decade for Africa Traditional Medicine, 15-17 January 2002, Scientific Technical Research Commission of the African Union, Lagos, Nigeria.

Monniaux, D., Caraty, A., Clement, F., Dalbiès-Tran, R., Dupont, J., Fabre, S., Gereard, N., Mermillod, P., Monget, P., Uzbekova, S. 2009. Développement folliculaire et ovulation chez les mammifères. Inra Productions Animals, 22: 59-76.

Mora, O.A., Cabrera, M.M., Sanchez-Criado, J.E. 1994. Hormonal pattern of the pheromonal restoration of cyclic activity in aging irregularly cycling and persistent estrus female rats. Biology of Reproduction, 51: 920-925.

Nazrullaev, S.S., Bessonova, I.A., Akhmedkhodzaeva, Kh.S. 2001. Estrogenic activity as a function of chemical structure in Haplophyllum quinoline alkaloids. Chemistry of Natural Compounds, 37: 551-555.

N'Guessan, K. 2008. Plantes Médicinales et Pratiques Médicales Traditionnelles chez les Peuples Abbey et Krobou du Département d'Agboville (Côte d'Ivoire): Etudes Botaniques, Tri Phytochimique et Pharmacologique. Thèse de doctorat d'Etat, 289 pp., UFR Biosciences, Université de Cocody, Abidjan, Côte d'Ivoire.

N'Guessan, K. 1995. Contribution à 1'Etude Ethnobotanique en Pays Krobou (République de Côte d'Ivoire). Thèse de doctorat $3^{\text {ème }}$ cycle, 526 pp., Faculté des Sciences et Techniques, Université de Cocody, Abidjan, Côte d'Ivoire.

Papreen, N., Sharma, A., Sabin, K., Begum, L., Ahsan, S.K., Baqui, A.H. 2000. Living with infertility: experiences among urban slum populations in Bangladesh. Reproductive Health Matters, 8: 33-44.

Patel, S.S., Soni, H., Mishra, K., Singhai, A.K. 2011. Recent updates on the genus Passiflora: A review. International Journal of Research in Phytochemistry and Pharmacology, 1: 1-16.

Rosen, H., Jameel, M.L., Barkan, A.L. 1989. Regulation by estradiol of serum levels of L.H. and F.S.H and pituitary levels of gonadotrophin-releasing hormone receptor after ovariectomy in the rat. Journal of Endocrinology, 123: 249-256.

Seidhova-Wuttke, D., Becker, T., Christoffel, V., Jarry, H., Wuttke, W. 2003. Silymarin is a selective estrogen receptor beta $(\mathrm{ER} \beta)$ agonist and has estrogenic effects in the metaphysis of the femur but no or antiestrogenic effects in the uterus of ovariectomized (ovx) rats. Journal of Steroid Biochemistry and Molecular Biology, 86: 179-188.

Shinnosuke, K.M.D., Masahiko, H.M.D. 1994. Developmental changes in pituitary function during the prepubertal period in female rats. Asia-Oceania Journal of Obstetrics and Gynecology, 9: 345-351.

Shughrue, P.J., Lane, M.V., Merchenthaler, I. 1997. Comparative distribution of estrogen receptor- $\alpha$ and- $\beta$ mRNA in the rat central nervous system. The Journal of Comparative and Neurology, 388: 507-525.

Shupnik, M.A. 1996. Gonadotropin gene modulation by steroids and gonadotropin releasing hormone. Biology of Reproduction, 54: 279-286.

Shupnik, M.A., Rosenzweig, B.A. 1991. Identification of an estrogen-responsive element in the rat LHB gene. Journal of Biological Chemistry, 266: 1708417091.

Smith, B.D., Bradbury, J.T. 1961. Ovarian weight response to varying doses of estrogens in intact and hypophysectomized rats. Proceedings of the Society for Experimental Biology and Medicine, 107: 946-949.

Thakur, S., Bhavana, B., Dubey, A., Nandini, D., Chauhan, N.S., Saraf, D.K. 2009. Effects of Carum carvi and Curcuma longa on hormonal and reproductive parameter of female rats. International Journal of Phytomedicine, 1: 31-38.

Unissa, S. 1999. Childlessness in Andhrea Pradesh, India: treatment-seeking and consequences. Reproductive Health Matters, 7: 54-64.

Vaissaire, J.P. 1977. Sexualité et Reproduction des Mammifères, Maloine (ed.), 457 pp., Paris, France.

Wassarman, P.M., Albertini, D.F. 1994. The mammalian ovum. In: The Physiology of Reproduction. E. Knobil and J. D. Neill (eds.), vol. 11, pp. 79-122, 2 ${ }^{\text {nd }}$ edition, Plenum Publ. Co., New York, USA.

WHO. 2002. WHO Traditional Medicine Strategy 20022005, 74 pp., World Health Organization (WHO/ EDM/TRM2002.1), Geneva, Switzerland.

Zarrow, M.X., Yochim, J.M., McCarthy, J.L. 1964. A Source Book of Basic Techniques, 39 pp., Experimental Endocrinology, (Eds.), Academic Press, New York, USA. 